industry of the neolithic levels is of the characteristic Palestinian type. Although Palestine is not likely to rival Iraq in the number and intrinsic value of its archæological finds, the sense of its importance grows as further exploration brings to light cumulative evidence of the part it played as a meeting place of cultural influences from a diversity of directions.

\section{Portrait of Owen at the Natural History Museum}

THE Trustees of the British Museum have received by the bequest of Mr. Cyril B. Holman-Hunt, who died last year, the portrait of Sir Richard Owen, which was painted in 1881 by his father, the wellknown artist, William Holman-Hunt, O.M. It has been hung on the east pier near the main entrance in the Central Hall of the Natural History Museum. The picture was in the possession of the artist's daughter, Mrs. Joseph, but she readily acceded to her brother's wishes as expressed in his will, and arranged for its transference from the Athenæum, where it was temporarily on loan. In the picture, Owen is depicted in Hunter's gown seated in an armchair. The position in the Central Hall is far from suited to a glazed picture, but it is the best at present available in the building; the trustees have, however, undertaken to provide one more satisfactory whenever the public part of the Museum is extended. It is fitting that the portrait should find a place at South Kensington, because Owen was superintendent of the Natural History Departments of the British Museum from 1856 until 1884. He had therefore a great say in the planning of the new building and the allocation of space in it to the several departments, and was in control when the building was opened to the public, on April 18, 1881. Incorrectly but justifiably, he is usually known as the first director of the Museum. In addition to the distinction of the subject, the picture has considerable interest as a work of art, because the eminent artist seldom engaged in portraiture, and only about five examples of that side of his work are known.

\section{British Empire Cancer Campaign}

AT the fifty-fourth meeting of the Grand Council of the British Empire Cancer Campaign held on April 10, it was announced that a grant at the rate of $£ 350$ a year for the year 1935 has been made to Sir Leonard Hill for the services of Dr. T. Reiter whilst continuing his research work on short wave therapy in the laboratories of the St. John Clinic and Institute of Physical Medicine. On the recommendation of the Physical Sub-Committee of the Scientific Advisory Committee, a grant of $£ 1,000$ a year for two years has been made to the North of England Council of the Campaign, to be placed at the disposal of Prof. W. E. Curtis, of the Armstrong College, Newcastle, and Dr. F. Dickens, research director of the Cancer Research Institute of the North of England Council, for the purpose of con. ducting an exhaustive scheme of research in short wave therapy. A grant of $£ 700$ has been placed at the disposal of the Scientific Advisory Committee for a special investigation, under its supervision, of the biological reactions of monochromatic radiations of various wave-lengths. The Grand Council has decided to continue to offer from time to time a prize and medal for the best essay submitted on a set subject concerning cancer research; gold medals will also be awarded from time to time to those in the British Empire who have carried out and published contributions to cancer research of outstanding merit.

\section{New Mount Everest Expedition}

The Mount Everest Committee announces that another Mount Everest Expedition will take place during 1935-36, with the consent of the Tibetan Government. Mr. Hugh Ruttledge, who led the 1933 expedition, has been offered, and has accepted, the leadership. The Committee, the chairman of which is Sir Percy Cox, will in due time make an announcement of plans. The first Mount Everest expedition under Col. H. Bury was in 1921. This was followed by a second expedition under General C. G. Bruce in 1922, and a third under Lieut.-Colonel E. F. Norton in 1924. On that expedition, Mr. G. A. Leigh-Mallory and Mr. A. C. Irvine lost their lives in the last thousand feet of the ascent, but it is not improbable that they reached the summit. The fourth expedition, in 1933, met with exceptionally bad weather conditions and was forced to abandon the attempt when success seemed to be within sight. In 1933, the Houston Mount Everest expedition made a flight over the summit and secured photographs.

\section{Field Trials of Agricultural Crops}

Further reports of the field trials carried out in Great Britain under the auspices of the National Institute of Agricultural Botany have been published in its Journal (vol. 3, No. 3. 2s. 6d.). As before, stress is laid on the necessity for carrying out the experiments at several centres simultaneously, and for repeating them for three consecutive years, before really reliable recommendations can be made. The results of the trials of cereals in Essex (1927-29) are now complete. 'Yeoman' and 'Yeoman II' proved by far the best of the winter wheats, and all autumn sown varieties were on an average $\mathfrak{f 3}$ per acre more valuable than those sown in the spring. As regards barley, 'Plumage Archer' was the most generally grown, although 'Spratt Archer' gave quite as satisfactory yields. Autumn sowing if successful was profitable, a gain of $£ 2$ per acre being obtained, but the risk of bad winter con. ditions has, of course, to be taken into account. 'Grey Winter' proved the hardiest and best yielder of the winter oats grown, but both standing and yielding capacity were lower than desired. Spring oats generally gave a higher yield than winter varieties. In every case the advisability of early sowing is emphasised, not later than the middle of November for autumn sowing, and during February for the spring varieties. The growing of named, rather than unknown, varieties is also of the first importance, as it may mean a difference of as much as $\mathfrak{£} 3-\mathfrak{- 1 4}$ per acre in the value of the return. Results from potato and sugar beet trials are also given, and 